Institute for Research on Poverty

Discussion Paper no. 1190-99

\title{
The Changing Economic Status of U.S. Disabled Men: Trends and Their Determinants, 1982-1991
}

\author{
Robert Haveman \\ Department of Economics and La Follette Institute of Public Affairs \\ University of Wisconsin-Madison \\ E-mail: haveman@lafollette.wisc.edu \\ Karen Holden \\ La Follette Institute of Public Affairs and Department of Consumer Science \\ University of Wisconsin-Madison \\ E-mail: holden@lafollette.wisc.edu \\ Barbara Wolfe \\ Departments of Economics and Preventive Medicine \\ University of Wisconsin-Madison \\ E-mail: wolfe@lafollette.wisc.edu \\ Paul Smith \\ Office of Tax Analysis \\ U.S. Department of the Treasury \\ Kathryn Wilson \\ Department of Economics \\ Kent State University
}

March 1999

This research was partially supported by a grant from the Social Security Administration. Conclusions represent those of the authors alone and not of the funding agency. The authors gratefully acknowledge the help of John Wolf and Dawn Duren.

IRP publications (discussion papers, special reports, and the newsletter Focus) are now available on the Internet. The IRP Web site can be accessed at the following address: http://www.ssc.wisc.edu/irp/ 


\begin{abstract}
In this paper, we track the level of economic well-being of the population of men who began receiving Social Security Disability Insurance (SSDI) benefits in 1980-81 from the time just after they became beneficiaries (in 1982) to 1991, nearly a decade later. We present measures of the economic well-being of disabled individuals and their nondisabled peers as indicators of the relative economic position of these two groups. These measures also provide an intertemporal comparison of well-being and hardship as disabled persons and their nondisabled peers age and retire. We first show several economic well-being indicators for this group of new male recipients of disability benefits in 1982 and 1991. Then, we compare their economic position to that of a matched group of nondisabled males with sufficient work histories to have been disability-insured, that is, eligible for SSDI benefits had they been unable to engage in substantial gainful employment. Because labor market changes over this decade have led to a relative deterioration in the position of younger and less-educated workers, we compare men with disabilities to those without disabilities and distinguish different age and educational levels within the groups. In studying these comparative trends in well-being, we focus on the prevalence of poverty and its correlates. We conclude by assessing the antipoverty effectiveness of Social Security income support for both younger and older men who became SSDI recipients in 1980-81.
\end{abstract}




\section{The Changing Economic Status of U.S. Disabled Men, 1982-1991: Trends and Their Determinants}

The past two decades have seen major changes in the work patterns of men in the United States, including increases in the pace of early retirement (Quinn, Burkhauser, and Myers 1990), the incidence of joblessness (especially among young workers with low educational attainment), and wage rate inequality among workers (Danziger and Gottschalk, 1995). Moreover, the earnings gap between younger and older workers has increased dramatically, as has that between low-skilled and high-skilled workers (Levy and Murnane, 1992). These changed labor market patterns have long-term consequences for men with work-limiting disabilities.

Labor market opportunities for workers with disabilities determine the advantage of continuing market work relative to receiving public transfer benefits. ${ }^{1}$ In making this choice, disabled workers implicitly or explicitly assess their future trajectory of labor market opportunities and compare this with the trajectory of income flows should they receive disability benefits. This latter assessment also depends on expected labor market opportunities since Social Security disability benefits in the United States are tied both to the number of years worked and to earnings during working years. Hence, the decision to continue to work made at any wage will alter the trajectory of Social Security disability benefits received in the future. ${ }^{2}$ Moreover, this work-continuation/benefit-recipiency decision faced by men with

\footnotetext{
${ }^{1}$ Although many individuals with disabilities have labor market opportunities, we recognize that many persons with severely limiting conditions will not. For a fuller discussion of the labor market choice of men with disabilities, see Haveman and Wolfe (1984), Leonard (1986), Bound (1989), and Haveman, de Jong, and Wolfe, (1991). In addition, both Bound and Burkhauser (forthcoming) and Haveman and Wolfe (forthcoming) survey the recent literature on the consequences of SSDI and other public transfer programs on the behavior and well-being of people with disabilities.

${ }^{2}$ This is also true for most employer-provided disability benefits as well, but is not true of Supplemental Security Income (SSI) benefits paid to low-income persons who are aged, blind, and disabled. The benefit amount in SSI is a fixed family-size-conditioned amount available to those who are eligible, having passed an income and assets means test.
} 
disabilities requires assessments of both options based on uncertain information about labor markets and public policy changes.

This work-continuation/benefit-recipiency assessment may differ substantially between younger and older workers with disabilities. For young workers with impairments, early receipt of U.S. Social Security Disability Insurance (SSDI) benefits means that they forgo any sharing in the standard earnings gain pattern over the life cycle, which gain will be experienced by most of their nondisabled peers. ${ }^{3}$ On the other hand, for those young impaired workers with low schooling levels and few skills, SSDI benefits and the accompanying Medicare coverage may yield higher net income than does labor market work, in spite of the sacrifice of life-cycle earnings increases. Hence, for younger workers with health limitations, the decision to apply for SSDI benefits is likely to be taken by those with the poorest labor market prospects.

For older disabled workers, on the other hand, SSDI benefits may be a bridge to early retirement (Haveman, Warlick, and Wolfe, 1988; Berkowitz, 1997). Disabled workers who apply for and receive benefits before age 65 are not assessed an early retirement penalty, and the earnings averaging period is truncated at their date of disablement. ${ }^{4}$ In addition, SSDI may bring eligibility for Medicare at a younger age than 65, the age at which retired-worker beneficiaries become eligible for Medicare. Thus, older workers able to meet the Social Security disability criteria—which are somewhat relaxed at ages 50 and 55 (Ycas, 1996) - may assess early SSDI application as a better option than (1) later application for SSDI

${ }^{3}$ This is so because SSDI benefits are restricted to severely disabled workers; eligibility for benefits is forgone if earnings exceed a very low earnings limit ( $\$ 500$ per month).

${ }^{4}$ Application for SSDI between ages 62 and 64 eliminates the early retirement reduction that would otherwise be imposed for receipt of retired-worker benefits. Application before age 62 reduces the years over which covered earnings would otherwise be averaged. Social Security benefits are based on Average Indexed Monthly Earnings (AIME), which is equal to total indexed covered earnings averaged over the number of years between 1956 or age 25 (whichever is later) and age 62 or the year prior to disability. A worker who left covered work at age 55 would have an AIME calculated over a period that included 7 years of zero earnings and a benefit that was reduced by 20 percent. If the worker was able to qualify for disability at age 55, the averaging period would be reduced by those 7 years and no actuarial reduction would be imposed. 
benefits or (2) delaying receipt (and, presumably, continuing to work) until becoming eligible for retiredworker benefits.

The differences in the nature of the work-continuation/benefit-recipiency choice between younger and older workers point to the importance of distinguishing younger and older SSDI recipients in assessing the relative economic status of the disabled. Because the trajectories of economic status of SSDI recipients compared to like-aged individuals without disabilities are likely to be quite different for younger and older cohorts, this distinction must also be made in assessing the effectiveness of SSDI benefits in maintaining the relative well-being of disabled workers over time.

In this paper, we track the level of economic well-being of the population of men who began receiving SSDI benefits in 1980-81 from the time just after they became beneficiaries (in 1982) to 1991, nearly a decade later. We present measures of the economic well-being of disabled individuals and their nondisabled peers as indicators of the relative economic position of these two groups. These measures also provide an intertemporal comparison of well-being and hardship as disabled persons and their nondisabled peers age and retire. We first show several economic well-being indicators for this group of new male recipients of disability benefits in 1982 and 1991. Then, we compare their economic position to that of a matched group of nondisabled males with sufficient work histories to have been disabilityinsured, that is, eligible for SSDI benefits had they been unable to engage in substantial gainful employment. ${ }^{5}$ Because labor market changes over this decade have led to a relative deterioration in the position of younger and less-educated workers, we compare men with disabilities to those without disabilities and distinguish different age and educational levels within the groups. In studying these comparative trends in well-being, we focus on the prevalence of poverty and its correlates. We conclude

${ }^{5}$ Eligibility for SSDI depends on (1) meeting the definition of disability: the inability to engage in substantial gainful activity by reason of "physical or mental impairment" that is expected to last at least a year or result in death, and (2) being eligible for Social Security (having at least 20 quarters of coverage or if younger than 31 , having quarters equal to 50 percent of those since age 21). Once eligible, after a waiting period of 2 years, a person is eligible to receive Medicare coverage. 
by assessing the antipoverty effectiveness of Social Security income support for both younger and older men who became SSDI recipients in 1980-81.

\section{DATA AND PROCEDURES}

The 1982 U.S. Social Security Administration's New Beneficiary Survey (NBS) provides a reliable basis for studying the level and trend of economic well-being of U.S. men and women with severe disabilities. ${ }^{6}$ However, because our primary sample consists of men who are SSDI beneficiaries at the time we first observe them, we cannot examine the economic forces associated with the onset of their work-limiting health condition, or the factors that led to their choosing SSDI beneficiary status over continued labor force participation. By employing another, longitudinal data set with information comparable to that included in the NBS — the Michigan Panel Study of Income Dynamics (PSID)—we are able to compare the economic status of SSDI beneficiaries over time with that of a sample of men without disabilities. These comparisons reveal the long-term differences in economic well-being between comparable groups of men with and without severe work-limiting disabilities, and hence the well-being consequences of the occurrence of such health conditions.

Consider first our NBS data on disabled men. The NBS surveyed a sample of individuals who first received U.S. Social Security benefits between June 1980 and June 1981 (Ycas, 1992). Surviving

${ }^{6}$ Because the male disabled population that qualifies for SSDI benefits is a subset-and by some estimates a minority —of the male working-age population with functional limitations, our results apply only to men with sufficient work histories to meet SSDI eligibility and whose work limitations are sufficiently severe to apply for and be approved for SSDI cash benefits. By limiting our analysis to the severely disabled SSDI recipients, we are excluding other men with substantial work limitations who may have lower levels of economic well-being because SSDI benefits are not available to them. 
respondents and surviving spouses were resurveyed in 1991; 66.7 percent of the 1982 male disabled respondents were still alive in 1991, and 88.1 percent of them were reinterviewed. ${ }^{7}$

New male SSDI beneficiaries who were 20-65 when first interviewed in 1982 and who were reinterviewed in 1991 constitute our primary sample. ${ }^{8}$ To construct the nondisabled male comparison group, we use the PSID, from which we selected a sample of nondisabled men who in 1980 had a sufficient work history to gain SSDI benefits should they have experienced a serious work-limiting disability. Like the sample of SSDI recipients, these nondisabled men were aged 20-65 in 1982, the year corresponding to the NBS interview. We selected our nondisabled sample in 1980 since it was in that year that the NBS sample was first identified as sufficiently disabled to be eligible for SSDI benefits. The comparison sample consists of the 1991 survivors of this group.

We matched our samples of disabled and nondisabled men by calculating weights derived from the distribution of the NBS disabled male sample across cells defined by race, age, education, and marital status. When these weights are applied to the 1982 PSID nondisabled sample, these two groups of men

${ }^{7}$ Those men who attrite from the sample are very similar to those who remain. There are no statistically significant differences in the means of the income variables for either an older or a younger disabled sample between those who continue in the sample until 1991 and those who attrite. For older men, those who attrite have lower poverty rates (13.5 percent versus 15.1 percent for those who remain), but the difference in average income is less than $\$ 40$. For the younger sample, poverty rates are the same, but mean income for attritors is about $\$ 800$ more than for those who continue in the sample, suggesting that the difference in income is at the higher income levels. A probit estimation of the likelihood of attriting supports the claim that those who attrite are similar to those who remain. Although the attritors have slightly higher education levels, the coefficient estimates on the income variables are not statistically significant. For further analysis of mortality in the NBS, see McCoy, Iams, and Armstrong (1994), who show that disabled men had generally stable death rates over this period, with probability of death not influenced by socioeconomic status among the disabled.

${ }^{8}$ In a related paper (Haveman, Holden, Wolfe, Smith, and Wilson, forthcoming), we study levels and trends in relative well-being of women SSDI recipients. For earlier studies of the economic well-being of persons with disabilities, see Burkhauser, Haveman, and Wolfe (1993), Haveman and Wolfe (1990), Grad (1989), and Weaver (1997). The latter two studies focus on the economic well-being of recipients of various forms of Social Security benefits. See also Bound and Burkhauser (forthcoming) and Haveman and Wolfe (forthcoming). 
have identical distributions of these labor market and demographic characteristics. ${ }^{9}$ Our sample consists of 2,110 disabled men and 2,621 matched nondisabled men. The Appendix describes the selection and matching process in more detail. ${ }^{10}$

\section{MALE RECIPIENTS OF DISABILITY INCOME TRANSFERS: A PROFILE}

Table 1 presents descriptive statistics for our (surviving) sample of disabled men in 1982 (after they first received SSDI benefits) and in 1991. The average age of the men was 51.0 years, and they averaged only 10 years of schooling. About 17 percent of them were nonwhite, and just under threefourths of this disabled group were married. They were not a well-to-do group; mean family income in 1982 (in 1994 dollars) was about $\$ 21,700 .{ }^{11}$ In a year when 14 percent of all U.S. families were poor, 21 percent of the families of these male SSDI recipients lived in poverty. ${ }^{12}$ The average ratio of their family income to the family-size-specific official U.S. poverty line was $2.1 .{ }^{13}$ Only about 36 percent of the families of these disabled men reported any earnings by either the disabled male or his wife. Annual

${ }^{9}$ The matching cell weights applied to the PSID nondisabled comparison group in effect redistributes them across the relevant cells such that equal percentages of disabled (NBS) and nondisabled (PSID) men are included in each cell. Hence, the well-being patterns calculated for the population of nondisabled males reflects economic position for a sample of nondisabled males with the same 1982 labor market and demographic characteristics as the SSDI recipients.

${ }^{10}$ Although an SSDI beneficiary must be under age 64 at the time of application (in 1980-81 for this sample), by the 1982 interview some had reached age 65. Although the Social Security Administration administratively redefines disabled beneficiaries at age 65 as retired-workers, there is no change in benefit amount. Analytically, we continue these disabled in SSDI status.

${ }^{11}$ The 1982 income of the male SSDI recipients is the extrapolation to 1 year of 3 months of income recorded after they began receiving SSDI benefits. Because the NBS collected income data consistently for only the disabled individual, his spouse (if married), and children under 18, we define the sum of the incomes of these individuals to be family income. Similarly, the sum of these individuals equals the size of the family of the disabled man.

${ }^{12}$ This reflects the official U.S. poverty measure, which compares the annual cash income of a family with a family-size-conditioned needs threshold (or poverty line). Those families with income below the relevant poverty line are classified as poor. Other indicators of poverty are also commonly applied in the U.S. context, including a comparison of a family's income with 1.5 times the relevant poverty line.

${ }^{13}$ This ratio is known in the literature as either the "family income-to-needs ratio," or the "welfare ratio"; we use the former term. 
TABLE 1

Newly Entitled Male Recipients of Social Security Disability Insurance Benefits: 1982-1991

\begin{tabular}{|c|c|c|c|c|c|}
\hline & \multirow[b]{2}{*}{ All Men } & \multicolumn{2}{|c|}{1982} & \multicolumn{2}{|c|}{1991} \\
\hline & & $<55$ & $55+$ & $<55$ & $55+$ \\
\hline \multicolumn{6}{|l|}{ Demographic characteristics } \\
\hline Mean age (years) & 51.0 & 41.0 & 60.0 & 49.5 & 68.5 \\
\hline Mean education (years) & 9.9 & 10.5 & 9.4 & 10.5 & 9.4 \\
\hline$\%$ nonwhite & $17.4 \%$ & $20.0 \%$ & $15.1 \%$ & $20.0 \%$ & $15.1 \%$ \\
\hline$\%$ married & $73.8 \%$ & $63.1 \%$ & $83.4 \%$ & $61.2 \%$ & $76.1 \%$ \\
\hline Mean family size & 2.4 & 2.6 & 2.1 & 2.1 & 1.9 \\
\hline$\%$ in South & $39.2 \%$ & $40.0 \%$ & $38.5 \%$ & n.a & n.a \\
\hline$\%$ in West & $15.7 \%$ & $16.2 \%$ & $15.3 \%$ & n.a & n.a \\
\hline$\%$ in Northeast & $17.6 \%$ & $15.9 \%$ & $19.1 \%$ & n.a & n.a \\
\hline \multicolumn{6}{|l|}{ Family income characteristics } \\
\hline Mean total family income & $\$ 21,724$ & $\$ 19,430$ & $\$ 23,767$ & $\$ 19,157$ & $\$ 21,291$ \\
\hline Mean income-to-needs ratio & 2.13 & 1.84 & 2.39 & 1.98 & 2.26 \\
\hline$\%$ poor & $20.9 \%$ & $29.6 \%$ & $13.2 \%$ & $24.2 \%$ & $9.9 \%$ \\
\hline Families with transfer/pension income & $95.7 \%$ & $92.7 \%$ & $98.4 \%$ & $86.8 \%$ & $99.7 \%$ \\
\hline Families with earnings & $36.4 \%$ & $39.3 \%$ & $33.8 \%$ & $39.7 \%$ & $17.8 \%$ \\
\hline Disabled individuals with earnings & $6.6 \%$ & $10.2 \%$ & $3.5 \%$ & $14.5 \%$ & $4.2 \%$ \\
\hline Men with spouse earnings & $31.8 \%$ & $32.0 \%$ & $31.6 \%$ & $30.8 \%$ & $15.1 \%$ \\
\hline Families with asset income & $50.8 \%$ & $38.9 \%$ & $61.3 \%$ & $47.8 \%$ & $63.9 \%$ \\
\hline \multicolumn{6}{|l|}{ Mean family transfers plus } \\
\hline pension income & $\$ 12,808$ & $\$ 10,540$ & $\$ 14,829$ & $\$ 9,602$ & $\$ 15,666$ \\
\hline Mean family earnings & $\$ 5,449$ & $\$ 6,214$ & $\$ 4,767$ & $\$ 7,251$ & $\$ 2,218$ \\
\hline Mean personal income & $\$ 13,374$ & $\$ 12,001$ & $\$ 14,597$ & $\$ 12,409$ & $\$ 13,271$ \\
\hline Mean spouse income & $\$ 5,602$ & $\$ 5,273$ & $\$ 5,895$ & $\$ 5,555$ & $\$ 5,210$ \\
\hline Mean asset income & $\$ 2,340$ & $\$ 1,497$ & $\$ 3,091$ & $\$ 1,142$ & $\$ 2,717$ \\
\hline
\end{tabular}

Notes: 1982 data are only for individuals still in the sample in 1991. Figures in 1994 dollars. 
earned income (either the disabled man's own earned income or that of his wife, if married) averaged about \$5,500 and accounted for one-quarter of total family income. Not surprisingly for these male SSDI recipients, family transfer income (including Social Security benefits and retirement pensions) accounted for about 60 percent of family income, or an average of about $\$ 12,800$. Finally, while half of the families of these men received income from assets, the average amount was small, accounting for 11 percent of their total income. On average, the disabled men contributed (from all income sources, including SSDI benefits) about 62 percent of aggregate income of their families. The low labor force participation of their wives (only about one-third of these wives recorded any earnings) contributes to the relatively low level of economic well-being of their families.

The mean characteristics of the entire sample of SSDI recipients mask the quite different characteristics of the younger (aged less than 55 in 1982) and older (aged 55 years or more in 1982) disabled men. Columns 2 and 3 present the mean characteristics of these two age groups. Almost 30 percent of the younger group is poor, compared to 13 percent of the older disabled men; the average income-to-needs ratio of the older group is 30 percent higher than that of the younger group. The relatively advantaged position of the older group is due largely to a substantially higher level of transfer income $(\$ 14,829$ versus $\$ 10,540)$, which itself is attributable to a longer working career and, hence, higher predisability earnings. Asset income is also somewhat higher for the older group. Interestingly, the percentage of families with earnings (including those of the spouse) is only slightly lower among the older group. On average, the income of spouses is about the same in the two age groups, although far fewer of the younger cohort are married (see below).

The patterns of change in well-being over the subsequent decade also differed between the younger and older groups, as shown in columns 4 and 5. The average family income of the younger group of disabled men remained fairly constant, while that of the older group declined slightly (by about 10 percent). The decline in their average family size (by 0.2 and 0.5 of a person for the older group and 
younger group, respectively) offset family income changes; as a result the average family income-toneeds ratio increased over time for the younger group and declined by 5 percent for older men. In spite of the convergence over time, average family income of the younger group was only about 90 percent of that of the older group, and the percentage of the younger disabled group in poverty remained more than double that of the older group at the end of the period.

Transfer income received by both younger and older disabled men ( 82 percent of which is SSDI benefits) provided a fairly constant base of income support over the period, declining by 9 percent among the younger group and increasing by 6 percent among older disabled men. For the older group, the decline over time in both own earnings and the percentage with spouse earnings is consistent with their aging into retirement years. A few among the younger group increased their labor force involvement, but only a small number had left the SSDI rolls permanently by 1991 (Hennessey, 1997; Ycas, 1996). ${ }^{14}$ By 1991, the poverty rate had fallen from its 1982 level for both groups of disabled males, to less than 10 percent among older men and to 24 percent among younger men.

\section{HOW DO DISABLED MEN FARE RELATIVE TO THEIR NONDISABLED COUNTERPARTS?}

To understand how the relative economic position of these two cohorts of disabled men changed over time and the role of SSDI in maintaining their relative economic well-being, it is necessary to compare them to a group of nondisabled men with identical labor market and demographic characteristics. Table 2 presents mean characteristics of the disabled SSDI recipients compared to those of the nondisabled sample, matched to achieve identical distributions of age, marital status, education, and race.

\footnotetext{
${ }^{14}$ Less than 1 percent of older disabled men left SSDI and began working. While the labor force involvement of the younger disabled sample is larger than that of the older, only 6 percent of the younger sample left SSDI and began working.
} 
TABLE 2

Disabled and Matched SSDI-Eligible Nondisabled Men:

Changes in Economic Status, 1982 to 1991

\begin{tabular}{|c|c|c|c|c|}
\hline & \multicolumn{2}{|c|}{ Age $<55$ in 1982} & \multicolumn{2}{|c|}{ Age $55+$ in 1982} \\
\hline & 1982 & 1991 & 1982 & 1991 \\
\hline \multicolumn{5}{|l|}{ Family income } \\
\hline Disabled & $\$ 19,430$ & $\$ 19,157$ & $\$ 23,767$ & $\$ 21,291$ \\
\hline SSDI-eligible nondisabled & $\$ 42,053$ & $\$ 44,476$ & $\$ 38,200$ & $\$ 26,380$ \\
\hline Disabled as $\%$ of nondisabled & $46 \%$ & $43 \%$ & $62 \%$ & $81 \%$ \\
\hline \multicolumn{5}{|l|}{ Income-to-needs ratio } \\
\hline Disabled & 1.84 & 1.98 & 2.39 & 2.26 \\
\hline SSDI-eligible nondisabled & 4.16 & 4.42 & 3.95 & 2.78 \\
\hline Disabled as $\%$ of nondisabled & $44 \%$ & $45 \%$ & $61 \%$ & $81 \%$ \\
\hline \multicolumn{5}{|l|}{$\%$ in poverty } \\
\hline Disabled & $30 \%$ & $24 \%$ & $13 \%$ & $10 \%$ \\
\hline SSDI-eligible nondisabled & $10 \%$ & $10 \%$ & $9 \%$ & $15 \%$ \\
\hline Disabled as $\%$ of nondisabled & $316 \%$ & $240 \%$ & $141 \%$ & $68 \%$ \\
\hline \multicolumn{5}{|l|}{$\%$ below $1.5 \times$ poverty } \\
\hline Disabled & $56 \%$ & $47 \%$ & $31 \%$ & $30 \%$ \\
\hline SSDI-eligible nondisabled & $17 \%$ & $26 \%$ & $17 \%$ & $31 \%$ \\
\hline Disabled as \% of nondisabled & $329 \%$ & $181 \%$ & $182 \%$ & $97 \%$ \\
\hline \multicolumn{5}{|c|}{ Social Security as $\%$ of family income } \\
\hline Disabled & $56 \%$ & $55 \%$ & $57 \%$ & $66 \%$ \\
\hline SSDI-eligible nondisabled & $3 \%$ & $13 \%$ & $18 \%$ & $53 \%$ \\
\hline Disabled as $\%$ of nondisabled & $1639 \%$ & $420 \%$ & $317 \%$ & $125 \%$ \\
\hline \multicolumn{5}{|l|}{ Transfers as $\%$ of family income } \\
\hline Disabled & $64 \%$ & $61 \%$ & $63 \%$ & $69 \%$ \\
\hline SSDI-eligible nondisabled & $9 \%$ & $17 \%$ & $20 \%$ & $55 \%$ \\
\hline Disabled as $\%$ of nondisabled & $719 \%$ & $361 \%$ & $317 \%$ & $125 \%$ \\
\hline \multicolumn{5}{|l|}{ Pensions as $\%$ of family income } \\
\hline Disabled & $5 \%$ & $5 \%$ & $13 \%$ & $13 \%$ \\
\hline SSDI-eligible nondisabled & $2 \%$ & $7 \%$ & $10 \%$ & $17 \%$ \\
\hline Disabled as $\%$ of nondisabled & $278 \%$ & $69 \%$ & $126 \%$ & $76 \%$ \\
\hline
\end{tabular}

(table continues) 
TABLE 2, continued

\begin{tabular}{|c|c|c|c|c|}
\hline & \multicolumn{2}{|c|}{ Age $<55$ in 1982} & \multicolumn{2}{|c|}{ Age $55+$ in 1982} \\
\hline & 1982 & 1991 & 1982 & 1991 \\
\hline \multicolumn{5}{|l|}{ Earnings as $\%$ of family income } \\
\hline Disabled & $22 \%$ & $24 \%$ & $15 \%$ & $7 \%$ \\
\hline SSDI-eligible nondisabled & $79 \%$ & $63 \%$ & $50 \%$ & $8 \%$ \\
\hline Disabled as $\%$ of nondisabled & $28 \%$ & $38 \%$ & $30 \%$ & $86 \%$ \\
\hline \multicolumn{5}{|c|}{ Spouses' income as $\%$ of total - all individuals } \\
\hline Disabled & $20 \%$ & $20 \%$ & $19 \%$ & $21 \%$ \\
\hline SSDI-eligible nondisabled & $10 \%$ & $19 \%$ & $16 \%$ & $12 \%$ \\
\hline Disabled as $\%$ of nondisabled & $200 \%$ & $107 \%$ & $116 \%$ & $169 \%$ \\
\hline \multicolumn{5}{|c|}{ Spouses' income as $\%$ of total - married couples only } \\
\hline Disabled & $31 \%$ & $32 \%$ & $23 \%$ & $28 \%$ \\
\hline SSDI-eligible nondisabled & $19 \%$ & $25 \%$ & $19 \%$ & $16 \%$ \\
\hline Disabled as $\%$ of nondisabled & $160 \%$ & $129 \%$ & $124 \%$ & $181 \%$ \\
\hline \multicolumn{5}{|l|}{$\%$ married (matching variable) } \\
\hline Disabled & $63 \%$ & $61 \%$ & $83 \%$ & $76 \%$ \\
\hline SSDI-eligible nondisabled & $64 \%$ & $72 \%$ & $81 \%$ & $76 \%$ \\
\hline Disabled as $\%$ of nondisabled & $98 \%$ & $84 \%$ & $103 \%$ & $101 \%$ \\
\hline \multicolumn{5}{|l|}{ Family size } \\
\hline Disabled & 2.6 & 2.1 & 2.1 & 1.9 \\
\hline SSDI-eligible nondisabled & 3.1 & 2.7 & 2.5 & 2.1 \\
\hline Disabled as \% of nondisabled & $84 \%$ & $78 \%$ & $84 \%$ & $90 \%$ \\
\hline
\end{tabular}

Notes: 1982 data are only for individuals still in the sample in 1991. Figures in 1994 dollars 
Disability status - and the consequent withdrawal from the labor force by both the younger and older groups of SSDI recipients—-had a substantial effect on the economic well-being of the families of these men. However, among the disabled, the families of the older cohort fared much better than those of the younger cohort, both absolutely and relative to the families of comparable men without disabilities. ${ }^{15}$

Consider the younger cohorts of disabled and nondisabled men. For both 1982 and 1991, the level of household income and the income-to-needs ratio of the younger disabled men were about 45 percent of those of their nondisabled counterparts. In 1982, 56 percent of the younger disabled men lived in families that were poor or near poor (defined as an income-to-needs ratio of below 1.5), compared to only 17 percent of the families of the younger nondisabled men. Although mean income of the group fell somewhat from 1982 to 1991, the near-poor rate for the young disabled group decreased from 56 percent to 47 percent over the subsequent decade. Although the near-poor rate for the young nondisabled group rose over the decade (to 26 percent), in 1991 the risk of near poverty was still nearly twice as large for the younger disabled group as it was for their nondisabled peers. Hence, relative to their nondisabled counterparts, the younger cohort of disabled men remained at a serious economic disadvantage over this period.

In 1982, the older SSDI recipients had family incomes and income-to-needs ratios equal to about two-thirds of those of their nondisabled counterparts. Over the next decade, as the older group of nondisabled men experienced reduced incomes associated with retiring from the labor force, the economic conditions of these two groups converged. In 1991 mean income and the income-to-needs ratio of the families of the disabled stood at about 80 percent of those of the nondisabled men. Between 1982 and 1991 both the income and the average income-to-needs ratio of the nondisabled fell, while the

\footnotetext{
${ }^{15}$ It should be noted that a more comprehensive measure of economic well-being would dampen the income differences among the four comparison groups to some extent. Public in-kind transfers (e.g., food stamps and Medicaid) tend to be income-conditioned, with larger benefits accruing to lower-income groups. In addition, much of the transfer income received through the Social Security program is not subject to taxation.
} 
conditions of the disabled were more stable. In 1992 about 30 percent of the families of both of these older groups were either poor or near poor.

Table 2 also indicates the relative role of income transfers (in particular, Social Security_including SSDI) in maintaining family income of both the younger and older cohorts. In 1982, Social Security income was the major source of family income for both cohorts of disabled men, accounting for nearly 60 percent of total family income. By comparison, earned income is the largest income component of the families of the nondisabled men. Earned income accounted for 80 percent of family income for the younger nondisabled cohort, and for 50 percent for the older cohort (many of whom were early Social Security retired-worker beneficiaries). However, by 1991, although transfer income for the younger cohort of nondisabled men was slightly higher than it was in 1982, earnings continued to account for nearly two-thirds of total family income. In part this is due to an increase in the percentage of nondisabled men who were married and who, as a result, benefitted from the contribution of spouse earnings to family income. In contrast, by 1991 transfer income as a percentage of family income had risen for the older nondisabled cohort and approached that of their disabled peers. By 1991, earned income of the families of the older nondisabled men had decreased to about 8 percent of total family income.

Retirement among the older nondisabled group resulted in a sharply reduced share of total family income accounted for by earnings as well as an increase in the share accounted for by pensions and Social Security. Similar but far more modest changes are recorded for the older disabled group. As a result, the economic status of the older cohort of disabled men converged toward that of their nondisabled peers. By 1991 the percentage near poor was about 30 percent for both groups, and the mean income and mean income-to-needs ratio were only 20 percent lower among the disabled than among the nondisabled. Because of the reduction in the earned income of the nondisabled older group, the disablednondisabled income gap among older men fell from about $\$ 14,000$ to $\$ 5,000$. While the income-to-needs 
ratio of the disabled older men remained at about 2.3 , that for the families of their nondisabled peers fell by 30 percent, from 4.0 to 2.8 .

Among the younger nondisabled, the percentage married increased (with a consequent increase in the share of total family income contributed by the spouse), and, as some among this group retired, earnings fell as a percentage of family income and the share of family income accounted for by Social Security rose. The net effect on the relative economic status of the younger disabled was small. Although some convergence in percentage poor between the two groups is observed, mean income and income-toneeds ratio for this younger disabled group remained well below one-half of the mean level for the nondisabled. Hence, even though SSDI benefits offset some of the lost earnings of this younger group of disabled men, their economic position remained weak relative to that of the younger nondisabled group. This low level of income of the younger disabled group suggests difficulty in saving for later years, and hence little prospect for increased living standards over time.

To summarize:

- At the beginning of our observation period (1982), both the younger and older cohorts of disabled men had substantially lower levels of economic well-being than their nondisabled counterparts, and the younger cohort was substantially worse off than the older nondisabled recipients.

- $\quad$ The disparity between disabled and nondisabled men fell substantially over time for the older cohorts, while that disparity remained stable over time for the younger cohorts.

- $\quad$ These patterns are accounted for by

a) the rapid decrease in the earnings of the older cohort of men without disabilities as they and their spouses retired and withdrew from the labor force, substituting a lower level of transfer (largely, Social Security retirement) income for lost earnings, and

b) the increase in marriage rates and early retirement income for the families of younger nondisabled men.

- Because the increase in transfer income did not fully offset the earnings loss of the older nondisabled group, they recorded a decline in overall income and a doubling of the rate of poverty and near poverty. 
- $\quad$ Although the nondisabled older men remained economically better off than their disabled counterparts in 1991, the difference in well-being between these two groups diminished substantially over the 1982-1991 period. This convergence reflects the oft-recognized tendency of older people to trade off income for leisure, a behavior that accounts for the standard humpshaped age-income profile.

- $\quad$ The persistent lower income of the disabled younger cohort compared to both their nondisabled peers and the disabled older cohort suggests that the younger disabled cohort will enter their retirement years with substantially lower incomes than (1) those who entered the Social Security rolls as older disabled workers and (2) their nondisabled peers.

\section{PREDICTORS OF POVERTY STATUS AMONG DISABLED AND NONDISABLED MEN}

Our discussion in Section III revealed that SSDI recipients who enter the rolls at older ages (55 or more) have quite different characteristics than those who enter SSDI recipiency when they are younger. Moreover, both the younger and older disabled groups have important differences from their respective nondisabled cohorts. As we have shown, the younger group of SSDI recipients experienced low levels of well-being by every indicator, relative to people who entered the SSDI rolls when they were older and to younger nondisabled people with the same characteristics.

While the many differences in personal and family characteristics among the young-old and disabled-nondisabled groups are likely to be associated with the differences in well-being across the groups, cross-tabulation comparisons such as those reported in Section III do not enable us to determine the independent relationship to relative well-being of any single factor. In Table 3, we present results from a bivariate probit estimation of the correlates of poverty status designed to identify the independent relationship of various sociodemographic characteristics to this outcome. ${ }^{16}$ We estimate the model over

\footnotetext{
${ }^{16}$ Unobserved factors are likely to be correlated with a household's poverty status in both 1982 and 1991; that is, knowledge of poverty status in 1982 conveys information about the probability of poverty status in 1991. A bivariate probit model allows for correlation in the error terms of the two probit estimates, reflecting this likely persistence of unmeasured characteristics within the group over time. The large positive and significant rho value indicates the strong persistence of these characteristics over time. Note that the coefficients estimated in bivariate probit models cannot be interpreted as "marginal effects." The signs on the coefficients indicate the direction of the relationship, and the $t$-statistics indicate the statistical significance of the estimated relationship.
} 


\section{TABLE 3}

Bivariate Probit of Being below the Near-Poor Threshold, Disabled and Matched SSDI-Eligible Nondisabled Men Coefficient (Standard Error)

\begin{tabular}{|c|c|c|c|c|}
\hline \multirow[b]{2}{*}{ Variable } & \multicolumn{2}{|c|}{1982} & \multicolumn{2}{|c|}{1991} \\
\hline & Base & $\times$ Disabled & Base & $\times$ Disabled \\
\hline Constant & $\begin{array}{l}-1.920 \\
(0.218)\end{array}$ & & $\begin{array}{l}-1.323^{*} \\
(0.165)\end{array}$ & \\
\hline Disabled & $\begin{array}{c}1.552 * \\
(0.286)\end{array}$ & & $\begin{array}{c}0.559 * \\
(0.241)\end{array}$ & \\
\hline $\begin{array}{c}\text { Age in } 1982 \\
<35\end{array}$ & $\begin{array}{c}0.688^{*} \\
(0.170)\end{array}$ & $\begin{array}{c}0.160 \\
(0.228)\end{array}$ & $\begin{array}{c}0.014 \\
(0.133)\end{array}$ & $\begin{array}{c}0.532 * \\
(0.197)\end{array}$ \\
\hline $35-51$ & $\begin{array}{c}0.339 * \\
(0.152)\end{array}$ & $\begin{array}{l}-0.103 \\
(0.200)\end{array}$ & $\begin{array}{l}-0.297 * \\
(0.122)\end{array}$ & $\begin{array}{c}0.418 * \\
(0.176)\end{array}$ \\
\hline $55-58$ & $\begin{array}{c}0.137 \\
(0.168)\end{array}$ & $\begin{array}{l}-0.057 \\
(0.212)\end{array}$ & $\begin{array}{c}0.357^{*} \\
(0.122)\end{array}$ & $\begin{array}{l}-0.426^{*} \\
(0.181)\end{array}$ \\
\hline $59-61$ & $\begin{array}{c}0.681^{*} \\
(0.165)\end{array}$ & $\begin{array}{r}-0.781 * \\
(.213)\end{array}$ & $\begin{array}{c}0.458 * \\
(0.132)\end{array}$ & $\begin{array}{l}-0.746 * \\
(0.189)\end{array}$ \\
\hline $62-65$ & $\begin{array}{c}0.497 * \\
(0.160)\end{array}$ & $\begin{array}{l}-0.744 * \\
(0.210)\end{array}$ & $\begin{array}{c}0.495^{*} \\
(0.123)\end{array}$ & $\begin{array}{l}-0.791 * \\
(0.184)\end{array}$ \\
\hline Married & $\begin{array}{l}-0.024 \\
(0.772)\end{array}$ & $\begin{array}{l}-0.484^{*} \\
(0.124)\end{array}$ & & \\
\hline Single in 1982/Single in 1991 & & & $\begin{array}{c}0.398 * \\
(0.132)\end{array}$ & $\begin{array}{c}0.164 \\
(0.119)\end{array}$ \\
\hline Single in 1982/Married in 1991 & & & $\begin{array}{l}-0.122 \\
(0.078)\end{array}$ & $\begin{array}{l}0.369 * * \\
(0.191)\end{array}$ \\
\hline Married in 1982/Single in 1991 & & & $\begin{array}{l}-0.128 \\
(0.117)\end{array}$ & $\begin{array}{c}0.157 \\
(0.153)\end{array}$ \\
\hline
\end{tabular}


TABLE 3, continued

\begin{tabular}{|c|c|c|c|c|}
\hline \multirow[b]{2}{*}{ Variable } & \multicolumn{2}{|c|}{1982} & \multicolumn{2}{|c|}{1991} \\
\hline & Base & $\times$ Disabled & Base & $\times$ Disabled \\
\hline Children $<18$ Living at Home & $\begin{array}{c}0.217 * \\
(.030)\end{array}$ & $\begin{array}{c}0.167 * \\
(0.046)\end{array}$ & $\begin{array}{c}0.152 * \\
(0.032)\end{array}$ & $\begin{array}{l}-0.007 \\
(0.044)\end{array}$ \\
\hline White & $\begin{array}{l}-0.620 * \\
(0.077)\end{array}$ & $\begin{array}{l}0.199 * * \\
(0.119)\end{array}$ & $\begin{array}{l}-0.527 \\
(0.076)\end{array}$ & $\begin{array}{l}-0.009 \\
(0.115)\end{array}$ \\
\hline$<$ High School Education & $\begin{array}{c}1.226^{*} \\
(0.142)\end{array}$ & $\begin{array}{l}-0.324 * * \\
(0.180)\end{array}$ & $\begin{array}{c}0.758 * \\
(0.100)\end{array}$ & $\begin{array}{l}0.272 * * \\
(0.148)\end{array}$ \\
\hline Some High School Education & $\begin{array}{c}1.070^{*} \\
(0.146)\end{array}$ & $\begin{array}{l}-0.721 * \\
(0.187)\end{array}$ & $\begin{array}{c}0.757 \\
(0.103)\end{array}$ & $\begin{array}{l}-0.230 \\
(0.155)\end{array}$ \\
\hline High School Graduate & $\begin{array}{c}0.601 * \\
(0.142)\end{array}$ & $\begin{array}{l}-0.369^{*} \\
(0.177)\end{array}$ & $\begin{array}{c}0.236^{*} \\
(0.106)\end{array}$ & $\begin{array}{l}-0.068 \\
(0.154)\end{array}$ \\
\hline South & $\begin{array}{c}0.112 \\
(0.083)\end{array}$ & $\begin{array}{c}0.133 \\
(0.116)\end{array}$ & $\begin{array}{c}0.506^{*} \\
(0.073)\end{array}$ & $\begin{array}{l}-0.171 \\
(0.110)\end{array}$ \\
\hline Northeast & $\begin{array}{l}-0.359 * \\
(0.109)\end{array}$ & $\begin{array}{c}0.076 \\
(0.150)\end{array}$ & $\begin{array}{r}-0.043 \\
(.0965)\end{array}$ & $\begin{array}{l}-0.439 \\
(0.141)\end{array}$ \\
\hline West & $\begin{array}{l}-0.366^{*} \\
(0.127)\end{array}$ & $\begin{array}{c}0.451 * \\
(0.163)\end{array}$ & $\begin{array}{c}-0.198 * \\
(.099)\end{array}$ & $\begin{array}{c}0.209 \\
(0.144)\end{array}$ \\
\hline Rho & $\begin{array}{c}0.612 \\
(0.022)\end{array}$ & & & \\
\hline Mean dependent & .258 & & .275 & \\
\hline Log likelihood -4057 & & & & \\
\hline $\mathrm{N}=4731$ (disabled: $2110 ;$ non & $\mathrm{d}: 2621)$ & & & \\
\hline
\end{tabular}

Notes: Near-poor threshold is 1.5 times poverty threshold. Nondisabled sample is weighted with matching weights.

*Significantly different from 0 at the $5 \%$ level.

**Significantly different from 0 at the $10 \%$ level. 
the entire sample of disabled and nondisabled men, with the discrete dependent variables indicating being in poverty or near poverty in 1982 and in $1991 .{ }^{17}$ In columns 1 and 3, the coefficients and standard errors of the characteristics of independent variables are shown for the two years. Columns 2 and 4 show coefficients and standard errors on each correlate when it is interacted with being disabled. The algebraic sum of the coefficients in columns 1 and 2 (for 1982) and columns 3 and 4 (for 1991) indicates the effect of the variables on the disabled population. ${ }^{18}$

\section{$\underline{\text { Overall Relationships (Columns } 1 \text { and } 3 \text { ) }}$}

The Disabled variable in column 1 indicates that men entering the SSDI rolls in 1982 had a significantly higher probability of being poor or near poor than did men with the same matched characteristics but without disabilities. ${ }^{19}$ Compared to the excluded group of 52- to 54-year-olds, being aged less than 51-and particularly less than 35-is associated with a higher probability of being poor in 1982 for both the disabled and nondisabled groups. For the pooled disabled and nondisabled groups, being white and living in the Northeast or West (relative to the Midwest) decrease the risk of being poor

\footnotetext{
${ }^{17}$ In this analysis, we use the broader poverty measure-family income less than 1.5 times the familyspecific poverty line-for two reasons. First, the U.S. Social Security program is designed to provide higher benefits (relative to prebeneficiary income) for individuals with below-average prebeneficiary income. This redistributive goal is better captured by a more inclusive low-income standard than the more restrictive official U.S. poverty measure. Second, the near-poverty standard applied to the matched nondisabled population yields a weighted poverty measure equal to between 0.4 and 0.5 of median income for this group, hence increasing the comparability with the relative poverty indicator of 0.5 of median income used by many OECD countries. The absolute poverty or near-poverty indicator is the standard measure used in the U.S. context for assessing the targeting of public transfer benefits.

${ }^{18}$ While the results are displayed in this column format for ease in exposition, all of the variables for all four columns are included in the same bivariate probit estimation. We also estimated separate bivariate probit models for the disabled and nondisabled. Those results are consistent with the estimates discussed above based on the fully interacted model. A log-likelihood test of whether there is a statistically significant difference in the models for the disabled versus the nondisabled is significant at the 1 percent level (twice the log-likelihood difference was 284.2, which is distributed chi-square with 30 degrees of freedom). This result supports the need to run the model either separately or with the full interactions, as we do here. The separate estimates are available from the authors.

${ }^{19}$ This is not surprising, of course, given that when observed in 1982 the disabled were out of the workforce while the nondisabled, because they had to be currently insured for SSDI benefits to be included in the sample, were largely employed. However, this variable captures the effect of disability, allowing the other variables to capture differences among the disabled and between them and the nondisabled that are due to factors other than the influence of disability alone.
} 
or near poor. Conversely, having no postsecondary schooling ${ }^{20}$ and having children under age 18 living in the family increase the chance of being poor or near poor.

Column 3 shows the independent effect of the same set of variables on the probability of being poor or near poor in 1991. The Disabled variable is again positive and significant, but it has a substantially lower coefficient relative to its standard error than in the 1982 analysis. This is consistent with the results, shown above, indicating a convergence between the economic status of the disabled and nondisabled populations as the nondisabled substitute lower Social Security retirement benefits for higher earnings as they retire. ${ }^{21}$ By 1991, being less than 35 years old in 1982 (less than 44 years in 1991) has no different effect on the chances of being poor or near poor than being 52-54 in 1982 (61-63 in 1991) (the omitted category). In 1991, however, men older than the omitted category have a higher probability of being poor or near poor. ${ }^{22}$ The 1991 specification also measures the effect of changes in marital status over the 1982-1991 period on the probability of being poor or near poor in 1991 . Compared with those who are married in both years (the omitted category), being single over the entire period has a positive and statistically significant effect on the probability of being poor or near poor, while either becoming married or becoming single has no statistically significant effect on the poverty outcome. The effects of the other variables (race, children, schooling, and region) on the probability of being poor or near poor are generally consistent with the 1982 estimates.

\section{Relationships for the Disabled (Columns 2 and 4)}

The model estimates reported in columns 2 and 4 of Table 3 allow Disabled to have both a direct relationship to the probability of being poor or near poor and an indirect "effect" through the relationship

\footnotetext{
${ }^{20}$ The More than High School category is the omitted category in this estimate.

${ }^{21}$ Note that in Table 2 we showed that poverty rates for the younger disabled and nondisabled converged, even though other measures of economic status did not.

${ }^{22}$ This pattern is consistent with Table 2 and is expected, because men in the omitted category have a far lower prevalence of retirees who rely on social insurance transfers for income than do men aged 64 or more in 1991.
} 
of disability status and the other independent variables. For both years, the indirect effect of disability status is to diminish the effects of older age on the risk of poverty. ${ }^{23}$ Similarly, the effects on the probability of being poor or near poor of being white, having no postsecondary education, and living in the West are diminished for the disabled relative to the nondisabled for 1982. In contrast, having children less than 18 living in the household in 1982 increases the chances of being poor for the disabled relative to the nondisabled. ${ }^{24}$ For 1991, the significant effect of being a young disabled person on the risk of poverty complements our earlier finding regarding the persistent adverse effect on relative well-being of becoming disabled when young.

By 1991, the positive and significant relationship between the presence of minor children in the household and poverty risk among the disabled had disappeared, probably because there were fewer children under 18 (and therefore included in our family poverty thresholds) remaining in these homes. However, the relationship of low schooling among the disabled to the higher probability of being poor or near poor observed in 1982 was reinforced in 1991, perhaps reflecting the lower probability that these individuals were able to supplement low income with market earnings. Finally, becoming married between 1982 and 1991 increased the chances of being near poor for the disabled relative to the nondisabled. This may reflect differences in the nature of marriage opportunities for the disabled relative to the nondisabled, and the fact that becoming married to a spouse younger than age 62 (even if she had her own dependent children) would not qualify the family for additional SSDI benefits.

\footnotetext{
${ }^{23}$ The pattern of coefficients on the age dummy variables indicates a distinct inverted-u-shaped age-income profile for the nondisabled population in both 1982 and 1991. The pattern for our population of disabled new 1982 beneficiaries has no discernible peak, implying persistently rising incomes over the life cycle. We thank an anonymous referee for this insight.

${ }^{24}$ The marriage estimate may be because spouses caring for dependent children may be eligible for a Social Security benefit. That additional children increase rather than reduce poverty risk among the disabled, despite benefits paid to minor children of disabled beneficiaries, may reflect the maximum constraint on family SSDI benefits.
} 


\section{$\underline{\text { Simulation Results }}$}

We now use the bivariate probit coefficients of Table 3 in a simulation exercise designed to reveal the difficult-to-interpret quantitative magnitude of assumed values of selected variables on the probability of being poor or near poor in both 1982 and 1991 for the total population, and for the disabled and nondisabled subgroups. The results in Table 4 show the effect over both 1982 and 1991 of changing a single variable while holding the other variables constant, using both the level (columns 1 and 3) coefficients and the interaction (columns 2 and 4) coefficients of Table 3. These simulated probabilities are to be compared to the base probability (see top row of estimates). In effect, the simulations indicate the relative effects on the probability of being poor or near poor in both 1982 and 1991 for the total population, and for the disabled and nondisabled subgroups, if we assume that all individuals have the specified value of the characteristic indicated..$^{25}$

The effect of age is clearly seen in Table 4 (rows iv and v). If all the disabled men were young (<35 in 1982) when they became SSDI recipients, we would observe a far higher probability of being poor or near poor in both years. Conversely, if all the disabled men were older (62-65 in 1982) when they first received SSDI benefits, the probability (relative to the omitted prime-age category) of being poor or near poor would be reduced by one-third. The pattern among the nondisabled is quite different. For nondisabled men, being younger $(<35$ in 1982) is associated with only a slightly higher probability of being poor or near poor, and being older (62-65 in 1982) is associated with a higher probability of being poor or near poor (in contrast to a lower probability for the disabled) relative to the prime-age group. The age variables suggest the sharply better economic status for men who enter the SSDI rolls at or near age-eligibility for Social Security retired-worker benefits relative to those who enter the rolls

\footnotetext{
${ }^{25}$ The results are read as follows: In row ii, if we assume that all men in the sample are married in both years (as opposed to not being married in both years), the rate of poverty or near poverty will fall by 7.6 percent for the entire population, 10.2 percent for the disabled, and 3.5 percent for the nondisabled.
} 
TABLE 4

Simulated Probability of Being below the Near-Poor Threshold in Both 1982 and 1991

\begin{tabular}{|c|c|c|c|c|}
\hline & & Entire Sample & Disabled & Nondisabled \\
\hline \multicolumn{2}{|c|}{ Base probability } & .1804 & .2841 & .1129 \\
\hline \multirow[t]{2}{*}{ i) } & Those single in 1982 gain a spouse & .1709 & .2704 & .1061 \\
\hline & Percentage change & $-5.3 \%$ & $-4.8 \%$ & $-6.0 \%$ \\
\hline \multirow[t]{2}{*}{ ii) } & All men married both years & .1666 & .2551 & .1090 \\
\hline & Percentage change & $-7.6 \%$ & $-10.2 \%$ & $-3.5 \%$ \\
\hline \multirow[t]{2}{*}{ iii) } & All are white & .1495 & .2550 & .0809 \\
\hline & Percentage change & $-17.1 \%$ & $-10.2 \%$ & $-28.3 \%$ \\
\hline \multirow[t]{2}{*}{ iv) } & All are $<35$ years old & .2666 & .4802 & .1277 \\
\hline & Percentage change & $47.8 \%$ & $69.0 \%$ & $13.1 \%$ \\
\hline \multirow[t]{2}{*}{ v) } & All are aged $62-65$ & .1616 & .1892 & .1437 \\
\hline & Percentage change & $-10.4 \%$ & $-33.4 \%$ & $27.3 \%$ \\
\hline \multirow[t]{2}{*}{ vi) } & No one had kids & .1506 & .2379 & .0937 \\
\hline & Percentage change & $-16.5 \%$ & $-16.3 \%$ & $-17.0 \%$ \\
\hline \multirow[t]{2}{*}{ vii) } & On own (no kids and single) & .2067 & .3532 & .1114 \\
\hline & Percentage change & $14.6 \%$ & $24.3 \%$ & $-1.3 \%$ \\
\hline \multirow[t]{2}{*}{ viii) } & All at least a high school grad & .1095 & .1890 & .0578 \\
\hline & Percentage change & $-39.3 \%$ & $-33.5 \%$ & $-48.8 \%$ \\
\hline \multirow[t]{2}{*}{ ix) } & All single both years & .2405 & .4043 & .1340 \\
\hline & Percentage change & $33.3 \%$ & $42.3 \%$ & $18.7 \%$ \\
\hline
\end{tabular}


when young. Over time, the position of these men improves relative to both their nondisabled peers and the disabled who are younger when first receiving SSDI benefits.

Row viii indicates the independent effect of education. If men with less than a high school education are simulated to have graduated from high school (holding constant the education of all others), the probability of being poor or near poor is sharply reduced for both disabled and nondisabled men. We conclude that being young when first receiving SSDI benefits and having low education-two factors closely related to low labor market earnings- have especially serious negative effects on the wellbeing of disabled males; they are doubly disadvantaged.

Finally, consider the simulated effect of changes in family composition. If those who are single in 1982 are assumed to have a spouse by 1992 (row i), the probability of being poor or near poor falls somewhat for both the disabled and nondisabled groups. Similarly, the probability of being poor or near poor is (1) decreased if it is assumed that there are no children in the family (row vi) and if it is assumed that all men are married in both years (row ii), and (2) increased substantially for the disabled if it is assumed that there is no spouse or children present (row vii) or if the married men become single over the period (row ix). The risk of being poor or near poor falls substantially, especially for the nondisabled, if it is assumed that none of the men are racial minorities (row iii).

\section{THE ANTIPOVERTY EFFECTIVENESS OF SOCIAL SECURITY BENEFITS}

The evidence presented in Sections III and IV suggests that, although SSDI benefits provide an important cushion against the loss of earned income due to disability, the families of disabled men receiving SSDI benefits have substantially lower levels of economic well-being than do the families of men without disabilities and for a considerably longer period of their lives. In this section, we provide a quantitative assessment of the contribution of the Social Security program (primarily SSDI) to the wellbeing of the younger and older disabled men. We adopt three approaches to assessing the effect of the 
SSDI program on well-being, in each case measuring the effectiveness of SSDI benefits in maintaining well-being relative to a counterfactual in which Social Security income support is unavailable to people with disabilities.

In our first approach, we measure the effect of Social Security income in removing from poverty disabled men who, in the absence of these transfers, would be poor ${ }^{26}$ In our second measure, we first estimate the "poverty gap" for both the younger and older groups of SSDI recipients; we then calculate the extent to which Social Security benefits reduce that gap. Finally, we assess the "insurance" value of SSDI by comparing Social Security benefits actually received by disabled men with estimates of their predisability earnings.

The Antipoverty Impact of Social Security Benefits

In estimating the success of the Social Security program in removing the families of disabled men from poverty, we compare the actual poverty rate of these groups with the poverty rate that would exist if no Social Security benefits were paid. This calculation requires several steps.

First, we calculate the family income of each disabled SSDI recipient if they did not receive SSDI and Supplemental Security Income (SSI) benefits. By comparing this pre-Social Security income level for each family with its family-specific poverty line, we calculate the proportion of this disabled population that would have been poor in the absence of Social Security benefits, a pre-Social Security poverty rate." 27 This is shown in row i of Table 5.

\footnotetext{
${ }^{26}$ Our calculations here use the poverty threshold, as opposed to the poverty plus near-poverty thresholds in the analysis in Section IV. Our conclusions are robust with respect to the specific poverty indicator used. We have chosen the poverty threshold for this analysis to enable comparison with studies assessing the antipoverty effectiveness of other transfer programs.

${ }^{27}$ The pretransfer calculation is standard in the public economics literature for measuring the antipoverty effectiveness of income transfer programs. To the extent that the provision of transfer income reduces the work and earnings of the disabled person or members of his family, the calculation would overstate antipoverty effectiveness. Because the recipients of SSDI benefits have very low residual work capacities, we judge that this potential bias is small.
} 
Then, because the families of some disabled people would be eligible for SSI disability payments were there no SSDI program, we estimate the SSI benefits that each family would receive, based on reported income other than Social Security and assets, ${ }^{28}$ and add this amount to pre-Social Security income. Comparing this adjusted income value with the poverty line yields a "pre-Social Security with simulated SSI" poverty rate (row ii). Finally, for each SSDI recipient, we compare the actual (post-Social Security) poverty rate (row iv) to these simulated poverty rates, which comparisons provide a measure of the extent to which Social Security benefits enable the population of disabled SSDI recipients who would be poor in the absence of Social Security benefits to escape poverty (row v).

Table 5 presents these calculations for both the younger and older groups of disabled men. In 1982, shortly after these men first received SSDI benefits, the pre-Social Security poverty rate stood at about 66 percent for the younger group and 54 percent for the older group. For both groups, SSI would provide very modest income support, reducing these very high poverty rates by only about 3 to 5 percentage points. However, with Social Security income included in the family income definition, actual poverty rates were less than one-half of this level—about 30 percent for younger disabled men and only 13 percent for older disabled men. We conclude that Social Security benefits removed 55 percent of the younger men and 76 percent of the older men from poverty. The greater antipoverty effectiveness of Social Security for older relative to younger men is attributable to two factors: (1) the higher average benefit levels paid to older men because of their higher predisability earnings and (2) the larger proportion of older disabled men who are married (and who therefore have spouses who are either working or also receiving Social Security benefits).

The antipoverty effectiveness of Social Security benefits is quite different 9 years after the disabled population first received SSDI benefits. By 1991, many in the older group (and their spouses, if

\footnotetext{
${ }^{28}$ The SSI benefits are simulated (rather than reported to the NBS) since we want to count the full SSI benefit for all persons who would be eligible for this program in the absence of SSDI.
} 
TABLE 5

Antipoverty Effectiveness of Social Security Benefits Disabled Men, 1982 and 1991

\begin{tabular}{lccccc}
\hline & \multicolumn{2}{c}{1981} & & \multicolumn{2}{c}{1991} \\
\cline { 2 - 3 } \cline { 5 - 6 } & $<55$ & $55+$ & & $<55$ & $55+$ \\
\hline i) Pre-Social Security poverty rate & $65.9 \%$ & $54.0 \%$ & & $60.1 \%$ & $64.5 \%$ \\
ii) Pre-Social Security with simulated SSI & $61.9 \%$ & $51.3 \%$ & $56.4 \%$ & $62.0 \%$ \\
iii) Poor simulated removed from poverty by SSI & $6.1 \%$ & $5.0 \%$ & $6.0 \%$ & $3.9 \%$ \\
iv) Actual post-Social Security poverty & $29.6 \%$ & $13.2 \%$ & & $24.3 \%$ & $10.0 \%$ \\
v) Poor actually removed from poverty & & & & \\
$\quad$ by Social Security & $55.1 \%$ & $75.6 \%$ & $59.6 \%$ & $84.6 \%$ \\
vi) Average poverty gap filled by Social Security & $75.8 \%$ & $85.4 \%$ & $80.2 \%$ & $93.5 \%$ \\
\hline
\end{tabular}

Notes: Poverty is defined as receiving total income below the needs threshold. "Aggregate poverty gap" is needs threshold minus pre-Social Security family income, summed over all poor families. "Poverty gap filled by Social Security" is the aggregate Social Security benefit received by pre-Social Security poor households divided by the aggregate poverty gap. 
married) are older than 62 years (when Social Security retired-worker benefits can first be claimed) and hence have fewer earners in the family unit. ${ }^{29}$ As a result, the pre-Social Security poverty rate increases from 54 to 65 percent. Because the actual poverty rate for the older group fell from 13 percent in 1982 to 10 percent in 1991, the antipoverty impact of Social Security benefits increased over this period. In 1991, almost 85 percent of the older group who were pre-Social Security poor were boosted over their familyspecific poverty line by Social Security benefits, an increase from the 76 percent in 1982 . For the younger group, the percentage of pre-Social Security poor families removed from poverty by Social Security benefits increased from 55 percent in 1982 to 60 percent in 1991. Overall, then, Social Security programs had a large and sustained effect in reducing poverty for both the younger group and older group of disabled men who became SSDI recipients in 1982, but it was more successful at doing so for the older disabled.

The Impact of Social Security Benefits on the Average Poverty Gap

An alternative measure of the antipoverty effectiveness of Social Security benefits is obtained by calculating the fraction of the "poverty gap"- the amount of perfectly targeted income that would have to be given to the families of the pre-Social Security (but with simulated SSI benefits) poor disabled men in order to bring the level of each family's income up to the poverty line ${ }^{30}$ - that is eliminated by the receipt of Social Security benefits.

Row vi of Table 5 shows that, in 1982, Social Security benefits filled 85 percent of the poverty gap for older disabled men and 76 percent for younger disabled men. By 1991, these percentages had increased to 94 and 80 percent. Again, Social Security benefits are seen to play an important role in

\footnotetext{
${ }^{29}$ At age 65, SSDI beneficiaries are automatically converted to retired-worker status. This is an administrative conversion that does not in any way change the benefits for which they are eligible. The only effect is to make them subject to the retired-worker earnings limits rather than SSDI's substantial gainful work activity test.

${ }^{30}$ This gap is equal to zero if the pre-Social Security (but with simulated SSI) income of a family is equal to or larger than the poverty threshold.
} 
reducing poverty for the families of both younger and older disabled men, though the effectiveness of the system is substantially greater for those men who entered the disabled rolls close to retirement age. A substantial number of younger disabled men—nearly one-quarter of them-remained poor nearly a decade after first entering the SSDI rolls, and even with Social Security benefits, 20 percent of the 1991 pre-Social Security poverty gap remained unfilled.

The Income Replacement Impact of Social Security Benefits

Our third measure of the income-support impact of Social Security is based on a comparison of what a disabled person receives in the form of Social Security benefits relative to an estimate of what that person could have earned had he not experienced a disability (and, hence, had not been an SSDI recipient). We present two estimates of this SSDI "insurance value," both calculated from Social Security-covered earnings records linked to the NBS data set. The question asked is the degree to which SSDI insures the individual's or family's predisability level of income.

Our first estimated replacement rate assumes that the maximum reported covered earnings (in 1994 dollars) represent the amount the disabled male earned prior to becoming disabled, or his current potential earnings had he not been disabled. We add this estimated amount to the total income of the family less Social Security and SSI income, and interpret this sum as the value of family income had the person not become disabled and instead continued to work at a job paying this maximum amount. The ratio of the family's actual income (including receipt of SSDI and SSI benefits) to this potential income value yields an insurance-type replacement rate that reflects the effect of SSDI benefits in maintaining the family's simulated without-disability income. 
Alternatively, we assume that average earnings over the years actually worked ${ }^{31}$ reflect the person's predisability earnings. To the degree that the year of maximum earnings was an unusual year for individuals, the average earnings measure may be a better measure of the earnings against which disability insurance could be purchased. ${ }^{32}$ This value is then added to the non-Social Security/non-SSI income of the family and is used as the denominator in calculating a second replacement rate. (The family's actual income-including receipt of SSDI and SSI benefits—again serves as the numerator.) Because the estimate of potential family income is lower in this second estimate, it provides a higher estimate of the insurance value of SSDI.

These replacement rates are shown in Table 6 for three categories of families headed by disabled men—-those whose actual incomes indicated that they were poor, near poor, and nonpoor—and distinguish between older and younger disabled men in these categories. ${ }^{33}$

\footnotetext{
${ }^{31}$ This procedure understates nondisability income to the degree that a person's disability is long-term, hence reducing potential earnings for several years. We note that private market insurance is and can only be provided against actual earnings, and not against "potential" earnings. Our procedure understates nondisability income to the extent that spouses compensate for the loss of husband's earnings by increasing their own work involvement. However, our prior analysis revealed little difference between the earnings of spouses of disabled and nondisabled persons (see Table 2).

${ }^{32}$ Because this average is calculated over the years that the person actually worked, it exceeds the average earnings value used to calculate SSDI benefits, which includes some years with zero earnings. We exclude the years of zero earnings because we are seeking an estimate of the insurance value of this benefit in terms of earnings replacement.

${ }^{33} \mathrm{An}$ example will aid in the interpretation of Table 6. Consider younger disabled men classified as poor (line 5). Actual average family income for this group of men was $\$ 7,631$ in 1982 . Had these men received no benefits from Social Security, but instead earned an amount equal to the maximum of their covered annual earnings, average family income would have been $\$ 22,188$. The ratio of these two values yields an insurance-type replacement rate of 34 percent. Alternatively, if their earnings potential had been taken as the average of their covered earnings, the average income of their families would have been $\$ 13,245$, or 58 percent of their nondisability income. Both the maximum and average values are based on the actual prior earnings of disabled persons receiving SSDI benefits and hence reflect the likely period of deteriorating health and work capacity experienced by many SSDI recipients prior to receiving benefits (see Livermore, 1995). As an alternative to these measures, we could have compared the earnings potential of the disabled person, given his human capital characteristics, with the value of Social Security benefits received. However, this approach would overestimate the individual's true earnings potential by failing to reflect this potential predisability earnings deterioration. It should be noted that our two estimates of the difference between potential (without-disability) family income and actual family income are measures of the family's loss of well-being attributable to the disability of the male head.
} 
TABLE 6

SSDI Replacement Rates of Predisability Earnings

Mean Predicted Family Income Using

\begin{tabular}{|c|c|c|c|}
\hline \multirow{4}{*}{$\begin{array}{l}\text { Mean } \\
\text { Actual } \\
\text { Income }\end{array}$} & \multicolumn{3}{|c|}{ Average } \\
\hline & Maximum & Predisability & Mean Replacement \\
\hline & Predisability & Earnings & Rate Using \\
\hline & Earnings & Work Years & Actual/Max. \\
\hline
\end{tabular}

$\underline{1982}$

Above poverty

$\begin{array}{llllll}<55 & \$ 30,760 & \$ 51,220 & \$ 38,110 & 60 \% & 81 \% \\ 55+ & \$ 29,786 & \$ 54,198 & \$ 40,033 & 55 \% & 74 \%\end{array}$

Near poverty

$<55$

$\$ 13,190$

$\$ 30,716$

$\$ 19,729$

$\$ 20,362$

$43 \%$

$37 \%$

$67 \%$

$\$ 32,750$

$59 \%$

In poverty

$<55$

$\$ 7,631$

$\$ 22,188$

$\$ 25,426$

$\$ 13,245$

$\$ 14,683$

$34 \%$

$58 \%$

$55+$

$\$ 8,026$

$32 \%$

$55 \%$

1991

Above poverty

$\begin{array}{llllll}<55 & \$ 28,066 & \$ 47,692 & \$ 35,055 & 59 \% & 80 \% \\ 55+ & \$ 25,953 & \$ 49,558 & \$ 35,232 & 52 \% & 74 \%\end{array}$

Near poverty

$<55$

$\$ 11,183$

$\$ 28,207$

$\$ 17,689$

$40 \%$

$63 \%$

$55+$

$\$ 11,538$

$\$ 30,091$

$\$ 18,309$

$38 \%$

$63 \%$

In poverty

\begin{tabular}{llllll}
$<55$ & $\$ 7,082$ & $\$ 22,158$ & $\$ 12,900$ & $32 \%$ & $55 \%$ \\
$55+$ & $\$ 8,297$ & $\$ 23,294$ & $\$ 13,140$ & $36 \%$ & $63 \%$ \\
\hline
\end{tabular}

Notes: Table includes survivors to 1991 only. Figures in 1994 dollars. Near poverty is between 1.0 and 1.5 times poverty threshold. 
For both the high and low estimate of mean predicted family income, the simulated withoutdisability family income of the older men is generally higher than that of younger men, consistent with the standard age-earnings profile. This pattern holds across the three well-being categories. However, and despite the progressive benefit formula, the actual benefits (plus other income) of families of SSDI recipients who are poor is a lower percentage of their estimated nondisabled income than it is for more well-off families, reflecting the more sporadic working careers and lower earnings of men in poor families. Finally, the difference between the high and low estimates reflects the impact of averaging earnings for beneficiaries whose earnings may have deteriorated because of disability well before applying for SSDI. ${ }^{34}$

\section{SUMMARY AND CONCLUSIONS}

The disabled men in our sample-those who entered SSDI beneficiary status in 1982 and survived to 1991—have a substantially lower level of economic well-being than their nondisabled but SSDI-eligible peers. In 1982 about 50 percent of the families of the disabled men were either poor or near poor-56 percent of the younger group (those who first received SSDI before age 55) and 47 percent of the older group. The rate of poverty or near poverty for the nondisabled comparison group was about one-half this level.

Over the subsequent decade, as family structure changed (e.g., the death of spouses, with the loss of both their earnings and their income needs), SSDI benefits remained nearly constant, providing a reliable base of income support for the families of disabled men. By 1991, the poor-plus-near-poor rate for the SSDI recipients recorded for 1982 had fallen slightly to 47 percent for the younger disabled and

\footnotetext{
${ }^{34}$ The SSDI recipients in poor families have more years with zero earnings prior to receipt of benefits, reducing the actual benefit award and the "insurance value" of SSDI against lost earnings, which are estimated only across the working years. The negative effect on predisability earnings of the ultimate onset of disability has been studied by Livermore (1995).
} 
30 percent for the older disabled, while the rate for the nondisabled group edged up. As a result, the wellbeing gap between the two groups narrowed significantly as both groups aged. Indeed, by 1991 about 30 percent of the families of both the disabled and nondisabled older groups were either poor or near poor. For the younger groups, however, the poor-plus-near-poor rate for the disabled (47 percent) remained at nearly twice the level of the rate for the nondisabled population.

For both 1982 and 1991, the probability that the families of both groups of men (disabled and matched nondisabled) are poor or near poor is positively associated with their being young (less than 35 years old in 1982), having a low level of schooling, being unmarried, and having children under 18 living in the family. The effect of being young when first receiving SSDI benefits is especially strong and persists over the first 10 years of benefit receipt. This age pattern carries two implications. First, it suggests that, in spite of a progressive benefit formula, SSDI benefits have a greater effect in reducing the prevalence of poverty or near poverty for recipients who enter the rolls when they are older than it does for those who become disabled and, hence, recipients earlier in life. Second, it suggests that those who become disabled earlier in life are disadvantaged by sacrificing the experience-related earnings growth that accrues to the nondisabled. We conclude that those who first receive SSDI benefits early in life are doubly disadvantaged relative to their nondisabled peers-in addition to experiencing the disutility of the disabling condition, they sacrifice higher earnings for lower benefits, and they forgo the growth of future earnings associated with age and experience.

SSDI recipients who remain single over the period experience much higher rates of poverty or near poverty than continuously married men do, suggesting that the added spouses contribute more to family income than to income needs. Interestingly, however, moving from being single to being married appears to increase the probability of poverty among the disabled, and probably reveals the relatively low earnings capabilities of the potential spouses of disabled men. Having children in the family unit adds more to income needs, increasing the probability of being poor or near poor by about 5 percentage points 
for disabled men in both 1982 and 1991. This suggests that dependents' benefits fail to fully offset the greater economic needs of families with children.

Social Security benefits in the U.S. have played an important role in sustaining the economic status of families of disabled men. Nevertheless, the families of young men with disabilities remain a disadvantaged group, relative to their nondisabled counterparts and to older disabled men. Men who enter the SSDI rolls early in life cease work earlier; hence the gains that come with longer working careers are not reflected in their later Social Security (SSDI) benefits. Over time their relative economic position remains well below that of their nondisabled peers and of men who first receive SSDI at a later age. Although men who come on the SSDI rolls at a later age experience an increase in their poverty rates over time due to the partial replacement of earnings by Social Security retirement benefits, their longer working careers result in postretirement income levels that are higher than their younger peers. Indeed, over time, their economic status and that of their nondisabled peers converge, as those in the latter group substitute lower retirement benefits for earned income.

These findings contribute to our understanding of the economic well-being of families headed by a disabled male and are distinct from previous results by revealing decade-long trends in well-being for these families. The disadvantaged position of the families of disabled men (relative to their nondisabled counterparts), and especially the disadvantaged position of the families of disabled men who enter the SSDI rolls at young ages (relative to both older disabled men and their younger nondisabled counterparts), is cause for concern if, as many believe, the U.S. social insurance system has been assigned responsibility for reducing such inequities.

Several options are available if policymakers should desire to narrow these disparities via legislative measures. Here we simply mention a few, and note some important considerations associated with each. 
Given that about 80 percent of the pre-Social Security poverty gap is already filled by Social Security benefits, adjustment of the SSDI benefit formula by raising the insured income level at which the replacement rate factor decreases could increase the insurance value of SSDI for recipients (especially unmarried recipients) who enter the roles at younger ages and could close much of the remaining gap. Similarly, a small across-the-board benefit increase would reduce poverty rates for these vulnerable groups. ${ }^{35}$ Both of these approaches, however, lack target efficiency, with much of the aggregate increase in costs accruing to beneficiaries who are not poor.

A more targeted approach would involve increases in the level of SSI benefits for disabled persons, but this change would have to be integrated with the SSDI benefit formula. It would also raise the question of increasing SSI benefits for aged poor persons in order to reduce the poverty gap for this population.

Other options might include reintroducing a minimum benefit level, reducing the number of zeroearnings years that are included in the benefit formula, or crafting an adjustment factor to reflect forgone earnings growth experienced by those whose onset of disability occurs when they are young.

All of these measures have specific advantages and drawbacks, and they vary in the costs associated with equivalent reductions in the poverty rates of the targeted groups. Analysis of the economic and administrative costs and benefits of each is a necessary next step should an increase in the antipoverty effectiveness of U.S. social insurance policy be desired.

\footnotetext{
${ }^{35}$ Conversely, the effective reduction of benefits through downward adjustment of the price indexation formula would impose a high cost on these beneficiary groups with high remaining poverty rates.
} 


\section{Appendix}

\section{Creation of the PSID Matched Sample}

The PSID matched sample was created to provide a nondisabled group comparable to the NBS sample of disabled individuals. After removing disabled individuals from the PSID sample, weights were applied to the remaining observations to match the NBS joint distribution of age, education, sex, race, and marital status. By matching, we are assured that differences in economic well-being across the two samples are not driven by differences in these demographic variables.

Disabled individuals were identified in the PSID by using self-reported health status and program participation information. Heads of household who reported their health status as "disabled" and indicated that their disability reduced the amount of work they could do "a lot" were defined as disabled. In addition, all individuals who reported their employment status as "permanently disabled," all individuals under 59 who received Social Security benefits, and all individuals who received Supplemental Security Income (SSI) or Workers' Compensation were defined as disabled and removed from the sample.

SSDI receipt requires that an individual be both "fully insured" and have 20 quarters of coverage (QC) in the last 40 calendar quarters, including the quarter of disablement. Prior to 1978 (and covering most of the covered earnings of the NBS sample) a QC was credited if a minimum amount was earned in a calendar quarter. Beginning in 1978, a QC was credited on the basis of units of dollars in annual earnings up to a maximum (in 1978 for each $\$ 250$, with that amount increased annually by the rise in average covered wages). Four quarters (the annual maximum) may be earned now with sufficient covered earnings in one calendar quarter. A person is fully insured with the lesser of 40 QCs or QCs equal to the number of years elapsed between age 21 and the year before disablement. Receipt of SSDI also requires that, based on age, education, and work experience, the recipient be unable to engage in any kind of substantial gainful work and that the impairment must be expected to last at least 1 year or result in 
death. Using work histories in the PSID, we selected individuals who would have sufficient quarters to be eligible for Social Security should they become disabled and meet the disability standard for eligibility.

The NBS and PSID samples were matched nonparametrically. Each observation in the sample was classified into one of the 192 cells representing a particular combination of age, education, sex, race, and marital status. The possible values of the demographic characteristics were defined as follows:

Age (6 bins): 20-34, 35-51, 52-54, 55-58, 59-61, 62-65

Education (4 bins): < HS, some HS, HS grad, > HS

Sex (2 bins): women, men

Race (2 bins): white, nonwhite

Marital status (2 bins): married, single

The age categories were chosen to reflect key age groups relevant to eligibility for Social Security retired-worker benefits both in 1982 and as the cohort aged over the following 9 years. Matching was accomplished by creating a cell weight for each of the 192 cells defined as the cell frequency in the NBS divided by the corresponding cell frequency in the PSID. Weighting each observation in the PSID sample by the appropriate matching weight created a sample with the same joint distribution of demographics as the NBS. 


\section{References}

Berkowitz, Monroe. 1997. "Linking Beneficiaries with Return-to-Work Services.” In Disability: Challenges for Social Insurance, Health Care Financing and Labor Market Policy, edited by V. Reno, J. Mashaw, and B. Gradison. Washington, DC: National Academy of Social Insurance.

Bound, John. 1989. "The Health and Earnings of Rejected Disability Insurance Applicants." American Economic Review 79(3): 482-503.

Bound, John, and Richard Burkhauser. Forthcoming. "Economic Analysis of Transfer Programs Targeted on People with Disabilities." In Handbook of Labor Economics, Vol. 3C, edited by Orley Ashenfelter and David Card. Amsterdam: North Holland.

Burkhauser, Richard, Robert Haveman, and Barbara Wolfe. 1993. "How People with Disabilities Fare When Public Policies Change.” Journal of Policy Analysis and Management 12(2): 251-269.

Danziger, Sheldon, and Peter Gottschalk, 1995. America Unequal. Cambridge, MA: Harvard University Press.

Grad, Susan. 1989. "Income and Assets of Social Security Beneficiaries by Type of Benefit." Social Security Bulletin 52(1): 2-10.

Haveman, Robert, Philip de Jong, and Barbara Wolfe. 1991. "Disability Transfers and the Work Decision of Older Men.” Quarterly Journal of Economics 106: 939-949.

Haveman, Robert, Karen Holden, Barbara Wolfe, Paul Smith, and Kathryn Wilson. Forthcoming. "The Changing Economic Status of Disabled Women, 1982-1991: Trends and Their Determinants." In Essays in the Economics of Disability, edited by David Salkever and Alan Sorkin. Stamford, CT: JAI Press.

Haveman, Robert, Jennifer Warlick, and Barbara Wolfe. 1988. "Labor Market Behavior of Older Men: Estimates from a Trichotomous Choice Model.” Journal of Public Economics 36: 153-175.

Haveman, Robert, and Barbara Wolfe. 1984. "Disability Transfers and Early Retirement: A Causal Relationship?” Journal of Public Economics 24: 47-66.

Haveman, Robert, and Barbara Wolfe. 1990. "The Economic Well-Being of the Disabled: 1962-84." Journal of Human Resources 25: 32-54.

Haveman, Robert, and Barbara Wolfe. Forthcoming. "The Economics of Disability and Disability Policy." In Handbook of Health Economics, edited by Joseph Newhouse and Anthony Culyear. Amsterdam: North Holland.

Hennessey, John C. 1997. "Factors Affecting the Work Efforts of Disabled-Worker Beneficiaries." Social Security Bulletin 60(3): 3-19. 
Leonard, J. 1986. "Labor Supply Incentives and Disincentives for Disabled Persons." In Disability and the Labor Market, edited by Monroe Berkowitz and Anne Hill. Ithaca, NY: Industrial and Labor Relations Press.

Levy, Frank, and Richard Murnane. 1992. "U.S. Earnings Levels and Earnings Inequality: A Review of Recent Trends and Proposed Explanations." Journal of Economic Literature 30: 1333-1381.

Livermore, Gina A. 1995. "The Effect of Pre-Disability Poor Health on Earnings and Relative Economic Well-Being of Men with Disability: An Evaluation of the Social Security Disability Insurance Benefit Structure." Ph.D. dissertation, Department of Economics, University of Wisconsin-Madison.

McCoy, John L., Howard M. Iams, and Timothy Armstrong. 1994. "The Hazard of Mortality among Aging Retired- and Disabled-Worker Men: A Comparative Sociodemographic and Health Status Analysis." Social Security Bulletin 57(3): 76-87.

Quinn, Joseph, Richard V. Burkhauser, and Daniel A. Myers. 1990. Passing the Torch: The Influence of Economic Incentives on Work and Retirement. Kalamazoo, MI: W. E. Upjohn Institute for Employment Research.

Weaver, David A. 1997. "The Economic Well-Being of Social Security Beneficiaries, with an Emphasis on Divorced Beneficiaries." Social Security Bulletin 60(4): 3-17.

Ycas, Martynas A. 1992. "The New Beneficiary Data System: The First Phase," Social Security Bulletin 55(2): 20-35.

Ycas, Martynas A. 1996. "Patterns of Return to work in a Cohort of Disabled-Worker Beneficiaries." In Disability, Work and Cash Benefits, edited by Jerry L Mashaw et al. Kalamazoo, MI: W. E. Upjohn Institute for Employment Research. 